\title{
Structuri inferențiale în limba română veche. Condiţionalul și concesivul
}

\author{
Ștefan Găitănaru* \\ Facultatea de Litere, Universitatea din Pitești, Str. Gh. Doja 41, 110253 Pitești, România
}

\section{Despre articol}

Istoric:

Primit 12 februarie 2019

Acceptat 5 martie 2019

Publicat 7 mai 2019

\section{Cuvinte-cheie:}

paradox

oximoron

perioadă

ipotetic

adversativ

\begin{abstract}
Rezumat
Studiul de față își propune să evidențieze faptul că perioada condițională și cea concesivă sînt două forme de manifestare a raționamentului ipotetico-deductiv la nivelul limbajului natural. Au fost descrise în diacronie evoluția conectorilor, uneori cu sublinierea zonelor de interferență, valorile semantice impuse de componenta modală a predicativității și de determinismul contextual. Analiza evolutivă a conectorilor a scos în evidență faptul că limba română veche, pentru impunerea sensului procedural concesiv cunoaște, ca celelalte limbi romanice, o zonă mare de creativitate, dar, spre deosebire de acestea, își exercită și caracterul conservator. Conceperea celor două raporturi sintactice ca variante ale aceluiași sistem, urmărește proiecția stilistică (paradoxul și oximoronul), relația semantică și formală a conectorilor şi implicarea conectorilor coordonatori adversativi în polarizarea opozițiilor în limba română veche.
\end{abstract}

\section{Preliminarii}

1.1. În diversitatea enunțurilor există, în orice limbă, şi enunțuri inferențiale, care traduc anumite tipuri de raționament la nivelul limbajului natural, grație legăturii dintre limbă și gîndire.

Un astfel de raționament este cel ipotetico-deductiv sau condițional, care apare sub forma circumstanțialului condițional, cu reprezentare la nivel frastic și, mai puțin realizată, la nivel propozițional.

Studii mai recente, plecînd, probabil, de la organizarea periodică similară din limba latină (subordonata / protază + principala / apodoză), au sugerat o anumită legătură între subordonata condițională și cea concesivă. Astfel, concesivul este definit ca „excluderea unui raport de condiționare (de inferență) între două procese de comunicare" (GALR II, p. 559).

A fost implicată și o legătură a celor două cu subordonata cauzală: ,frazele concesive (...) alcătuiesc de fapt frazele negative ale celor condiționale și cauzale" (Ivănescu, 2004, p. 203).

S-a constatat chiar că grupul cel mai important al conectorilor concesivi, încă din secolul al XVI-lea, se constituie după „tiparul conector condițional + focalizator" (Zafiu, 2014, p. 211; cf. şi Avram, 1960, p. 158). În virtutea acestui lucru, unele lucrări de istoria limbii le-au abordat chiar sub un titlu comun (Conditionals and concessives), subliniind, de fiecare dată, zonele de interferență (soR, p. 526-537).

S-a arătat, de asemenea, că ,Raportul concesivului cu termenul său regent constituie un paradox, deoarece piedica exprimată de condiţionalul concesiv permite, și nu contrazice—cum ar fi normal一desfăşurarea acțiunii şi existența însuşirii din regentă” (Căpăţînă, 2007, p. 261); și că „valoarea semantică globală a acestui domeniu se subsumează noțiunii de conexiune paradoxală” (Slușanschi, 1994, p. 60).

O altă provocare, oferită de această dată de texte, este aceea că multe condiționale și concesive sînt coordonate (corelate) cu principala (apodoza) prin conjuncții adversative. Unii autori, gîndindu-se la situația din latina populară, le-au numit circumstanțiale adversative (Barbu, 1943, p. 138). Dar raportul, el însuși, devansează subordonarea: „,...în astfel de fraze, propoziția secundară nu e la drept vorbind secundară, ci o propoziție subiect, iar propoziția principală e o propoziție predicat” (Ivănescu, 2004, p. 198).

*Adresă de corespondență: stefan_gaitanaru@yahoo.com. 
Ștefan Găitănaru

De unde s-ar deduce că e vorba de o dependență bilaterală: „il n’y a ni principale, ni subordonné, mais interdépendence de deux propositions solidaires qui ne peuvent exister l'une sans l'autre et n'ont de sens que l'une par l'autre" (Ernout \& Thomas, 1964, apud Slușanschi, 1994, p. 47).

În acelaşi sens, s-a precizat: „Pe plan logic, raportul dintre cele două propoziții este un raport necesar de implicaţie între secundară și principală. (...) condiţionala nu este un simplu element subordonat ideii comunicate în principală, ci un element care determină în mod necesar existența principalei, a cărei idee este implicată în principală” (Munteanu, 1998, p. 53).

1.2. Legătura dintre cele două poziții sintactice ca și înțelegerea zonelor de interferență semnalate de gramaticieni pot fi revelate prin analiză semantico-logică a tipului de implicaţie asumat de acestea.

Trebuie subliniat că perioada condiţională este, în fapt, un raționament, o inferență ipotetico-deductivă. De la aceasta, se poate ajunge la perioada concesivă printr-o transferare a protaselor de la varianta pozitivă la cea negativă a enunțului inferențial. Se pleacă, așadar, de la cele două variante: Dacă mă invițti, vin; Dacă nu mă inviți, nu vin. Prin schimbarea protaselor, se obține: Dacă mă inviți, nu vin; Dacă nu mă inviți, vin. Spre deosebire de condiție, concesia reprezintă o implicație antonimică. În structura raționamentului ipotetico-deductiv concesia înseamnă așadar fie negarea ipotezei, fie afirmarea unei concluzii negative (cf. GALR II, p. 592).

Pentru polarizarea opoziției, pentru a se constitui ca paradox, conectorului din protază i s-a adăugat un semiadverb intensiv (Zafiu, 2014, p. 211: focalizator), iar în precedența apodozei a apărut un adverb concesiv (chiar, și - tot, totuşi): (Chiar/ și) dacă mă inviţi, (tot / totuşi) nu vin; (Chiar / și) dacă nu mă inviți, (tot / totuşi) vin.

După ce, în evoluția limbii, anumiți conectori au dobîndit un sens procedural, specific, concesia s-a putut dispensa de negația de tip profrază (cf. Dominte, 2003, p. 20) a perioadei condiționale.

Stilistic, la nivelul frastic se poate vorbi de un paradox (cf. Dragomirescu, 1975, p. 170: Cînd nu sascundea nimica, deși tot era ascuns), iar, la nivel propozițional, de un oximoron (cf. Avădanei et al., 1994, p. 129) de tipul vrînd, nevrind; viu sau mort; de voie, de nevoie.

Gramaticienii au semnalat și legătura cu circumstanțiala cauzală (există chiar o cauzală indirectă sau condițională). S-a subliniat, de asemenea, că cei mai mulți conectori concesivi au și alte valori: „,condiționale, cauzale, locale sau modale" (Avram, 1960, p. 158).

Valoarea cauzală, cum se va vedea, este una dintre valorile de bază ale raționamentului ipoteticodeductiv (condițional).

Existența polisemiei conectorilor, contextual determinate, este firească în procesul instabil de specializare a lor (cf. și Zafiu, 2014, p. 213).

Raportul concesiv presupune concesia la mai mulți componenți ai enunțului, ceea ce se observă la conectorii relativi totalitari: concesia la subiect (Oricine vine, nu deschid), la complement direct (Orice aş mînca, mi se face rău), la alte valori circumstanțiale (oriunde, oricînd, oricum, oricît...).

Aceste aspecte diversificate, conservate în diacronie, oferă imaginea unui proces îndelungat de constituire și fixare a structurilor sintactice ale inferenței în limba română literară.

\section{Complexitatea structurii}

Din punctul de vedere al felului în care s-au fixat în limba scrisă, prin tehnicile asumate din traductologia primelor două secole, în legătură mai mult sau mai puțin directă cu structurile evoluate din latina populară, cele două raporturi (condițional și concesiv) diferă ca grad de dificultate.

2.1. Raționamentul ipotetico-deductiv, întrucît reprezenta o schemă cognitivă, făcea parte, în configurația silogismelor, din zona de bază, creativă, a gîndirii, reprezentînd capacitatea analitică a acesteia. Dar presupunea o schemă simplă, așa încît traducătorii l-au preluat (conector și structură), se pare, din limba vorbită 
(latina populară). Este consemnat ca atare și în celelalte limbi romanice (cf. cap. din Wagner, 1966, Les Phrases hypothétiques commençant par si dans la langue française, des origines à la fin de XVI siècle).

Simplitatea schemei sintactice a condus la avantaje și dezavantaje. La avantaje trebuie marcată frecvența normală a structurii, rezultată din posibilitatea directă de adaptare, prin traducere, la textul-suport. La dezavantaje este faptul că toți conectorii prototipici (dacă, de și cel etimologic, să), n-au dobîndit specificitate, lucru ce caracterizează, cum se va vedea, și limba română veche. În plus, singurul adverb condițional, altminteri, deși este consemnat încă din traducerile lui Coresi (el se întîlnește și astăzi), n-a reușit să se impună prin frecvență, asta poate pentru că, la nivel propozițional, poziția sintactică a condiției este în deficit faţă de manifestarea de la nivelul frastic.

2.2. Perioada concesivă, rezultatul unei inducții antonimice, presupune o schemă cognitivă mult mai complexă, iar rezultatul este o frecvență mult mai scăzută. Acest lucru a fost constatat: „Într-adevăr, textele din secolul al XVI-lea oferă foarte rare exemple de concesive. Și nu este vorba aici de o proporție mai redusă față de alte subordonate mai frecvente-proporție care poate fi aceeași și în limba actuală—ci se poate afirma că această specie era mai puțin folosită” (Avram, 1960, p. 153). Autoarea constată însă, la un examen paralel (același text, traduceri diferite în timp), diferențieri mari, în defavoarea textelor din secolul al XVI-lea. S-ar putea invoca mai multe cauze: calitatea traducătorilor; existența unui inventar mare de conectori polisemantici în limba română; dificultatea de înțelegere a tiparului sintactic de tip paradox de către receptori, de la copiști, pînă la beneficiarii mesajului.

La un examen paralel, se constată două atitudini. Prima presupune evitarea structurii, prin succesiunea

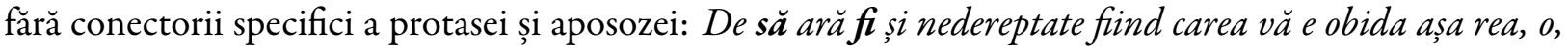
iudei, după cuvînt auzit ară fi voao sau să și întrebați... (СВ-СР, 195/3-5) - Se fie nedireptate fiindu care cumva sau obidă rrea, după cuvîntu, amu, asculta fire-(a)șu voi sau se intrebari... (Св, 195/3-5); fu de la Domnul propovedire, spăsenie și înviere, deși ainte a morților înviere și a să judeca cu trupul (СВ-СР, 297/3-4) - fu de la Domnului spunere spăsenie și îmviere. Și ceia ce inainte au murit... (Св, 297/3-4); supuneți-vă bărbaților voștri, de și cine se va potrivi cuvîntului mueresc... (СВ-СР, 311/2-3) - supuindu-se alelor săi bărbați, cel ce se potriveaște cuvîntului credincioasei mueri (св-Cv, 311/2-3).

$S$-a arătat mai înainte că evitarea conectorului putea fi determinată de inventarul mare al conectorilor. Într-adevăr, pentru acest secol, se consemnează un număr impresionant de 36 de conjuncții (simple, compuse, locuțiuni) și adverbe: ca, că, căce, cum, de, să; de se, că să; să nu nici, să amu și...; măcară să, măcară să și; dreptu căce, derep ce amu că să...; unde, de unde, io... (Avram, 1960, p. 154).

Dintre exemplele propuse însă (e adevărat că, inevitabil, sînt scoase din context), unele nu par a avea decît un slab sens concesiv (cf. și Zafiu, 2014, p. 13): Și cum era el fiul lu Dumnezeu, pentru aceea ce se munci, cu sficiune învăța; Ca eu cu trupul acolo nu sînt, ce cu dubul, aceea judec că aceia ce aşa aceea au lucrat... să-l dați acela Satanei; Și amu de sînt ce se grăiesc dumnezei sau în ceri sau în pămînt, că sînt dumnezei mulți sau domni mulți, ce noi avem un Dumnezeu părinte (Avram, 1960, p. 154).

Printre cele semnalate se află și cele care, în tendința de a se specializa, le domină prin frecvență pe celelalte (de... și; să... și, măcar și, măcar să...). Aceasta înseamnă că în secolul al XVII-lea, fenomenul evitării perioadei concesive prin structuri mai simple nu-și mai găsește motivația, fie că se păstrează raportul și conectorul, fie numai raportul: iară de am și știut pre Hristos după trup, iară de acum nu-l știm (NTB, 2Cor, 5, 16); iară de am și cunoscut trupeaște pre Hristos, iară acum nu-L mai cunoaștem (BВ, 2Cor, V, 16); Că de au și fost răstignit den slăbiciune, încă viiază den puterea lui Dumnezău (NT в, 2Cor, 13, 4); Că măcară că s-au și răstignit din slăbiciune, iară trăiaște den putearea lui Dumnezău (Bв, 2Cor, XIII, 4).

\section{Constituirea specificului semantic (a sensului procedural)}

O descriere exactă a sensului circumstanțial trebuie să țină cont de faptul că matricea acestuia este reprezentată de o structură corelativă. Astfel: circumstanțialul de loc (acolo..., unde), de timp (atunci..., cînd), de $\bmod ($ aşa..., cum); condițional (dacă/în caz că..., altminteri), concesiv (chiar dacă..., totuşi). Adverbul 
din structură domină clasa de substituție a circumstanțialului, la nivel propozițional, iar conectorul pe cea a elementelor de relație care inițiază subordonata la nivel frastic.

Gramatica normativă nu consideră că o astfel de matrice semantică este trăsătura de bază a circumstanțialului și recurge la o consemnare facultativă. Uneori consemnează ambele elemente: circumstanțialul de loc („,realizare definitorie adverbele unde (interogativ) / acolo” - GALR II, p. 514), de timp („,realizare definitorie atunci, cînd" - GALR II, p. 495); de mod (aşa, cum - GALR II, p. 523). La circumstanțialele de cauză, scop, condiție, concesie, consecuție sînt trecuți numai conectorii, iar la celelalte, deși sînt considerate, în mod discutabil, circumstanțiale, nu se specifică structura semantică.

Marcarea ambelor elemente ale structurii corelative este necesară, întrucît împreună dobîndesc un sens procedural și oferă astfel posibilitatea de a deosebi complementele de circumstanțiale.

3.1. Conectorii condiționali din protaza perioadei condiționale depind sub aspect semantic de structura raționamentului ipotetică-deductiv. El presupune un raport de implicație (consecință logică): Dacă eziuă, afară e lumină; un raport inductiv de cauzalitate: Dacă plouă, străzile sînt ude; un raport de antrenare inerțială a unei acțiuni de către alta: Dacă se face frig, aprind focul.

Întrucît timpurile absolute ale indicativului (prezentul, perfectul compus și, în mai mică măsură, viitorul) sînt deictice și au o componentă modală epistemică accentuată, raporturile dintre protază și apodoză pot fi transpuse ca succesiuni în timp (Cînd e ziuă, afară e lumină; Cînd plouă, străzile sînt ude; Cînd se face frig, aprind focul) și ca determinări cauzale (Fiindcă e ziuă, afară e lumină; Fiindcă plouă, străzile sînt ude; Fiindcă e frig, aprind focul).

Acest lucru, valabil pentru limbajul actual, a fost constatat și despre limba română veche: „La început, dacă avea o slabă valoare condiţională, valoarea ei principală fiind cea temporală și cauzală” (Frâncu, 2009, p. 149).

Exemple cu sens temporal sînt numeroase, implicînd chiar conectorul etimologic: Și deca se sfirșiră aceastea, dzise lu Pavelu Dubul (cv, 4 $\left.4^{\mathrm{r}} / 3-5\right)$; De trecură oarecare dzile, Agripa impăratu și Verrnichie deștinseră întru Chiesariia (cv, 34v/4-6); Să veri face bine, lua-veri plată (po, Bitia, 4, 7); Să tu de-stînga veri mearge, duce-mă-voiu eu de-a dereapta sau să tu in a dereapta veri mearge, eu în stînga voiu mearge (рО, Bitia, 13, 9); E deca se adunrară ei, grăi cătră-nşii (СВ-СР, 261/1-2); și deca auzi norodul glasul trîmbițelor, au chiuit tot norodul (BB, Navi, VI, 20); Și daca au înserat, l-au îmbrăcat cu haine proaste (GU, 77, 2/16-17); dacă s-au mai înglotit oastea s-au răsipitu cine încotro au putut (MC, 151, 1/25-27); Și dacă au audzit gîlceava la curte (...) au și purces spre curte (IN, 305, 2/25-27); Și dacă s-au făcut dzuă, s-au apropietu prin arini (IN, 306, 1/34-35).

Conectorul dacă se repetă uneori excesiv la începutul macrostructurilor sintactice, încît dobîndește o funcționalitate narativă: Și daca au înserat, s-au întorsu înapoi. A doao zi dacă au aflat moldovenii că leşii au dat dos a fugi s-au lăsat după după dînșii a-i goni. Și daca i-au ajunsu... (GU, 102, 2/27-30); daca au biruit acea strajă (...) și daca s-au impreunat toți (...) daca s-au întorsu oastea lui Ion-Vodă (GU, 104, 2/2, 10, 25); daca i-au venit cărțile crăiești (...) Acolo daca au venit l-au aflat (...) daca au sosit la vad după el (GU, 109, 1/19, 22, 28); Deaca s-au dusu la gazda lui Ureche (...) iar dacă au aflat că vornicul au trecut Nistrul (...) iar dacă Ureche au trecut Nistrul (GU, 118, 1/23-32); Deaca văzu că muri Saul, luo și el sulița (...) deca văzură că au fugit oștile (...) deaca înțeleseră ce au făcut păgînii lui Saul, să sculară toți (INB, I, 29/11-14).

Valoarea cauzală este la fel de bine reprezentată. De regulă, cauzala indirectă, prezentă și în limba română actuală, presupune o apodoză interogativă sau imperativă, dar, așa cum s-a văzut la tipurile de raționament, poate fi și enunțiativă: Iară de greșindu muncă rrebdați, carea e laudă? (cv, 75 /6-8); Și de sîntem negrijnici, să părăsimu negrija. Și să sîntemu färă usîrdie, să fimu cu usîrdie (cc² ,256/10-11);E deca se iuveaște adevărul piare minciuna ( $\left.\mathrm{FD}, 554^{\mathrm{v}}, 6\right)$; și deaca faci bine, nu-țipară rău (IN B, VIII, 211/1415); să ceva va fi rămîiend, ardeți cu foc (PO, Ishod, 12, 10); Dară de ce botezi, deaca nu ești tu Hristos (NTB, In , 1, 25); Să tu, fiind jidov, trăiești păgîneaște (...) pentru ce silești păgînii să să jidovească (NT B, Gal, 2, 14).

Întrucît, în mecanismul de determinare al gîndirii, circumstanțiala cauzală era strîns legată de cea de 
scop (cauza inițială și cauza finală), ele erau descrise, în gramaticile vechi, împreună (Tiktin, 1945, p. 233). Independent de gramaticieni însă, în limba veche, conjuncția de ... să (cu modul conjunctiv) exprimă finala, situație care, cu modul indicativ, se întîlnește, ca finală reală, și astăzi: Tremeaseră la elu de-lu rrugară se nu-și dea sinre întru zborriște (CV, 5\%/10-11); dzise cu rrane se-lu intreabe elu de se îțteleagă dereptu care vină așa strigă spri-nsu (CV, 22 $\left./ 12,22^{\mathrm{v}} / 1\right)$; Și acealea scriem voao de și bucuria noastră să fie deplină (СВ-СР, 327/1); Făgăduita ce ați auzit dentîiu, de să ne iubim unul la alalt (СВ-СР, 355/4-5); Și aceaia iaste poruncita lui de să creadem în numele Fiiului Isus (СВ-СР, 359/1); și deade noao înțelepciuni de să cunoaştem deadevărul (СB-CP, 371/4, 5); de să nu piiardem ce-am lucrat (СB-CP, 376/3, 4).

Constituirea sensului procedural a fost înțeleasă de unii specialiști ca o apropiere de conectorul prototipic: „treptat, această conjuncție (dacă, s.n.) se apropie din ce în ce mai mult de prototipul condițional care era conjuncția să” (Frâncu, 2009, p. 49). Dar, cum se observă din exemple, conectorul etimologic, atunci cînd este urmat de timpurile absolute ale indicativului, exprimă și el valorile reale ale cauzalității.

Pentru o eventuală asumare a sensului ipotetic (posibil) sau ireal trebuiau utilizate alte timpuri ale indicativului și alte moduri (condiționalul) cu ambele timpuri ale acestuia. După denumirea raționamentului (,ipotetico-deductiv sau condițional”) s-ar putea deduce că aceste două valori sînt specifice perioadei condiționale, condiționala reală fiind greu de delimitat de determinismul contextual. Poate că de aceea gramatica normativă reține și viitorul în structura acesteia, el făcînd parte din timpurile absolute ale verbului: „Se consideră condițională sigură subordonata care, în perioada ipotetică, specifică un proces prin intermediul formelor de indicativ (prezent, trecut și viitor)" (GALR II, p. 587).

În schimb, utilizarea formelor potențiale ale verbului poate conferi statut de conector condițional și altor relatori, care, în mod normal, au altă destinație sintactică: „Destul de des, condiționala este o propoziție introdusă prin cînd (...) atunci cînd modul verbului (atît în regentă, cît și în subordonată) este condiționalul: Așa cum însuşi Alfieri nu s-ar fi tradus mai bine, cînd ar fiștiut româneşte” (SLR, p. 344).

De aici și ideea că „specifice propoziției condiționale sînt dacă și de” (sLR, p. 43); „Totuși, cel mai frecvent, condiționala este introdusă prin dacă (sau prin sinonimul său de), care, în consecință, este considerat conectorul tipic pentru circumstanțiala condițională” (GALR II, p. 82).

Dar caracterul de specificitate (asumarea sensului procedural) și utilizarea frecventă sînt lucruri diferite. Astfel, dacă și mai ales, de pot introduce, în limba veche, o diversitate de subordonate: (atributivă) sîntu cu-rusul meșteri de au către neștinre cuvîntu (cv, 6\% /13-14); grămădi Pavelu vițe de vie multe de le punrea spre focu (cv, 48v/2-3); (finală) Întrămu de vînslămu și nă apropiem de Chipru (cv, 12v/11-12); (completivă directă) Judecă măriia-ta, ca un domn creștin, de iaste cu cale și de să cuvine să fu lipsit acuma, la bătrînețele mele, de amîndoao (AI, 230/24-26).

Condiționala (presupusă de vorbitor ca) reală cu verbul din protază la viitor este frecventă: De veri vrea, poți mă curăți ( $\mathrm{CB}, 435 / 5-6)$; De veri zice să vie, ea are a veni $\left(\mathrm{CC}^{2}, 251 / 21\right)$; de veri adeveri și veri avea muiare necredincioasă nu veri scăpa de nevoe (Mo, 137\%/4-5); Că de ați creade lui Moisi, doară ați creade și Mie (...) iară să nu veți creade scripturile lui, cum veți creade cuvintele Meale? (NTB, In, 5, 46); de nu-ți va fi grijă de poruncile lui Dumnezeu, nici vei băga în seamă învățătura mea (INB, I/20); Ii va da numai de-i va birui (GU, 74, 1/16); de nu-l va rădica și din țară și din domnie îl vor scoate ei cu oaste (GU, 76, 2/14-15); De vii vrea, vii putea (CI, 74/16-17); Deaca veți întra în cetate, așa îl veți afla pre el în cetate

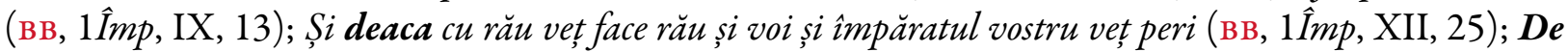
vei fi in ziua aceasta rob norocului acestuia și vei sluji lor și vei grăi cătră ei cuvinte bune, vor fi ție robi toate zilele (Bв, 3Împ, XII, 7).

Se întîlnește însă, la fel de frecventă, și condiționala ipotetică, introdusă prin dacă, de și să, unde sensul condițional nu se pune la îndoială: Se ară, amu, întra întru gloata voastră bărrbatu... întra-va și mișelu intru scîrnave veșminte ( $\mathrm{CB}-\mathrm{CV}, 274 / 5-7) ; \boldsymbol{S}$-ară Domnul vrea și, amu, a fivii să facem ceasta sau ceaia (CBCP, 289/3); Și să ară fi aibînd păcate, lăsa-se-vor lui (СВ-СР, 294/2); E s-am zice că nu greșim, minciune face-vrem (св, 329/1); Că de-ară avea credință desăvîrșitu cătră Dumnezeu n-arfi așa grijindu-se neîncetatu ( $\left.\mathrm{CC}^{2}, 243 / 20-22\right)$; de aşu mearge în mijloc de bănat, învie-me-veri ( $\left.\mathrm{PH}, 117^{\mathrm{r}} / 16-17\right)$; de nu s-ar hi prilejit o samă de capete să cerce mijloace... ar hi fostu de perire de istov țara aceasta (MC, 153, 1/24-26); de s-aru 
mai întoarce Duca-vodă, ei să nu vie cu dînsul (IN, 302, 2/5-6); de-ar hi lăsat pașa să margă tătarii după dînșii... puțini ar hi mersu cu dobîndă (IN, 465, 2/38-39); de nu ar hiperit el, nici într-un chip nu ar filuat turcii acea izbîndă (RG, 109/13-14); De s-ar fi potrivit domnul faptelor lor (...) de viață s-ar fi lipsit (RG, 131/36-37).

Valoarea ireală, ca frecvență, nu coincide cu frecvența redusă a condiționalului perfect, a imperfectului și a mai mult ca perfectului indicativ: Es-am zice că nu greșim, minciune face-vrem (св, 329/1-2); De te-ai teame de ruşine, n-ai grăi aşa (FD, 592\%/6-7); Că de-ară avea credință desăvîrşitu cătră Dumnezeu n-ar fi așa grijindu-se neîncetatu ( $\left.\mathrm{CC}^{2}, 243 / 20-22\right)$; de nu s-ar hi prilejit o samă de capete să cerce mijloace... ar hi fostu de perire de istov țara aceasta (MC, 153, 1/24-26); de-ar hi lăsat paşa să margă tătarii după dînşii... puțini ar hi mersu cu dobindă (IN, 465, 2/27-32); de nu ar hi perit el, nici într-un chip nu ar fi luat turcii acea izbîndă (RG, 109/13-14); Că de-așifif fostu în statulputerii mele, armasariul aşe tare nu m-ar fipurtat și de-așifi fost de vitioan aşe de iuşor, atîta de sus nu m-ar fi rădicat (CI, 95/2-6).

În ciuda numărului mare de variante ( $c a$, de, deca, deaca, daca, dacă, să, se, de...; cf. SLR, p. 257-258) conectorul condițional nu a reuşit pînă în secolul al XIX-lea să dobîndească un sens procedural, să aibă adică ocurență exclusivă în protaza condițională, așa cum s-a întîmplat cu mulți conectori concesivi.

Se pare că aceasta era o necesitate în limbă, din moment ce, atunci cînd s-a extins aria de comunicare, a fost preluată din franceză expresia în caz că (pentru concesivă, chit că).

Conectorul condițional este într-adevăr specific: „Realizarea definitorie a circumstanțialului condițional este propoziția conjuncțională introdusă prin în caz că” (GALR II, p. 582). El este explicat prin abandonarea determinării atributive a substantivului (în cazul cînd, în cazul că) prin dezarticulare: în caz că (cf. Iordan, 1954, p. 504; Avram, 1960, p. 196). Preluat în jurul anului 1700 (cf. DELLR, p. 79), ca neologism latino-romanic, substantivul $c a z$ a intrat ca suport în multe grupări frazeologice mai mult sau mai puțin sudate: în cazul acesta, în orice caz, in tot cazul, în cazul cînd...(cf. DLRLC, p. 351). Interesant este că printre acestea se află și locuțiunea prepozițională în caz de și locuțiunea conjuncțională în caz că, ambele cu utilizare condițională, exprimînd, de fapt, nu condiția, ci ipoteza (cf. Munteanu, 1998, p. 54).

Într-o ordine firească a lucrurilor, întrucît o propoziție circumstanțială este expansiunea la nivel frastic a unui circumstanțial (circumstanțialele fuseseră numite în gramaticile vechi complemente adverbiale (cf. Drăganu, 1945, p. 91), trebuie identificat adverbul cu sens condițional. Este vorba de adverbele altminteri şi altfel (cf. şi Iordan \& Robu, 1978, p. 675), ce substituie o protasă negativă: Dacă mă inviți, vin; Dacă nu mă inviți (altminteri) nu vin (cf. și GALR II, p. 89).

Se întîlnește destul de rar în limba veche: E acmu nu oprește, ce amintrileaș tăriia sa arată mai mare (apud Frâncu, 2009, p. 198; CC², 308); Şi aimintrea iară iaste minunată (apud Frâncu, 2009, p. 198; CC $^{2}, 342$ - cf. și ILRL, p. 157); Lorențu Topeltin, den Mediiaş, sas de-amintrilea, iară om învățat și destul umblat (ITR, 36 $/ 10,36^{\mathrm{V}} / 1$ ); era tînăr de zile, amintrilea era om mînios și pre lesne vărsa sînge (GU, 73 , a, 24-25).

Trebuie însă subliniat că adverbul din matricea semantică a codiționalului nu stabilește cu propoziția pe care o reia o relație de coreferențialitate. Astfel, într-un enunț de tipul Unde veri ceti leage, acolea- $i$ umbra legei ce-au trecut $\left(\mathrm{VO}, 20^{\mathrm{v}} / 17-18\right)$ avem o circumstanțială de loc coreferentă (alte studii o numesc apoziție, fără să implice în denumirea acesteia natura coreferențialității). În schimb, într-un enunț de tipul Dacă plătești, ți-o dau, altminteri nu, între protază și adverbul altminteri nu este o coreferențialitate directă, ci una negativă (altminteri = dacă nu plăteştie), ceea ce trimite la paradoxul structurii concesive. Așa se explică de ce unii gramaticieni l-au semnalat pe altminteri și în poziția sintactică a concesivului (Frâncu, 2009, p. 370).

Întrucît locuțiunile prepoziționale care puteau exprima un circumstanțial condițional (în locul, in caz de) au apărut mai tîrziu, exprimarea poziției se realizează frecvent prin gerunziu: Aibînd Fiiul Zeului, are viață, neaibînd Fiiul Zeului viață n-are (Св-CP, 369/2-3); au scris la pașe ... să-i sloboadă oamenii, că, neslobodzîndu-i, s-antoarce cu tot obuzul înapoi (IN, 465, 2/24-25); Dar cum ar fiputut face bine sau rău nefiind el? (INB, I, 11/9); voi să nu-i ascultați, văzînd că aceia au putere mai multă decît voi (INB, VIII, 211). 
3.2. Conectorii concesivi au o traiectorie mai clară în parcursul dobîndirii sensului procedural. Diversitatea lor, ca pluralitate de încercări, nu surprinde, dat fiind caracterul abstract și paradoxal al raportului logic pe care îl exprimă. În schimb, surprinde procentul mare de specializare a lor, începînd chiar din limba română veche.

Deși a circulat ideea că „În limbile romanice s-a constatat pierderea conectorilor concesivi, ale căror principale surse ar fi fost după Harris (1988, p. 76) tiparul indefinit, cel volitiv și cel temporal” (Zafiu, 2014, p. 212) aceasta este discutabilă cel puțin pentru limba română. Este adevărat, conexiunea paradoxală a concesivului cunoștea în latina clasică mai multe raportări: concesia la ipoteză (ut/ne); la determinismul cauzal sau temporal (cum); la comparație (quamquam, quamvis, quamlibet), dar și la condiționare (cf. Slușanschi, 1994, p. 60). Ultimul, se pare, a avut o productivitate mai mare în latina populară: „O arie destul de bine conturată este cea a concesivelor condiționale, deschise de si sau de compuși ai săi (...) marcarea clară a valorii concesive a subordonatei o dau conjuncțiile compuse etsi, și dacă, tametsi și etiamsi, chiar dacă” (Slușanschi, 1994, p. 60). Trebuie semnalat că în latina clasică, în texte (ca și în gramaticile ulterioare), elementele conjuncţiilor compuse apăreau și neaglutinate ca și în româna veche: „Les propositions concessives sont elle qui commencent: a) Soit par si (suivie dans la propositions principales, de tamen), ou par etiam si, et si” ... (Riemann, 1932, p. 378), cu anumite deosebiri semantice („etiam si ou et si signifiant quand même; etiamsi, ou etsi signifiant quoique", Riemann, 1932, p. 378).

Se pare că tiparul cel mai frecvent al concesivei funcționa fără prea multe modificări și în latina populară, din moment ce îl întîlnim identic în româna veche: și-l va rădica Dumnedzeu și s-are hi făcut şi păcate, ierta-să-vor lui (Vo, 8/9-10); și se n-are fi dzăcut cu nusa nu poci a me însura cu nusa că mi se prinde îmă (Prav.1581, 229 $-230^{\mathrm{r}}$, apud Stan, 2013, p. 254); cătră el trage pre noi și să n-am vrea noi, dulcele Dumnezeul nostru ( $\left.\mathrm{Cc}^{2}, 262 / 17-18\right)$.

Uneori diferă doar topica elementelor: să și n-avămu a trupului boală, iară inima noastră de pururea e păzită (cC $\left.{ }^{2}, 433 / 17-18\right)$; Și acolo iară să și bucate multe și în multe chipure să sîntu, însă puținu stau inainte ( $\left.\mathrm{CC}^{2}, 291 / 17-18\right)$.

$\mathrm{Nu}$ lipsesc nici formele etimologice (lat. et si - rom.v. e să): $\boldsymbol{E}$ să amu şi aceluiaşi Dumnezeu închinarăse, că crezură Samareanii și iudeii, însă Samareanii nu știia (cC $\left.{ }^{2}, 161 / 4-6\right) ;$... e să mie nu veți crede, lucrului mieu credeți (ст, 209-210, apud Avram, 1960, p. 155).

De aceea, anumite teorii ale creativității, cel puțin cele referiroare la limba română, trebuie măcar parțial reconsiderate: „Romanian, like the other Romance languages, lost the Latin concessive markers (the only exception could be măcar 'even') and rebuilt new connectives, sometimes using the same pattern" (sOR, p. 534).

Cu toate acestea, structura corelativă ce exprimă circumstanțialul concesiv în româna contemporană (chiar dacă..., totuși / etiam si..., tamen) ține de aceeași creativitate lexicală a vorbitorilor români.

De continuitate se poate vorbi cu siguranță, întrucît ce s-a afirmat despre concesivele condiționale latinești se poate spune și despre cele românești: „Cel mai important ca frecvență este grupul de conjuncții care au ajuns să introducă propoziții concesive pornind de la valoarea lor condițională” (Avram, 1960, p. 158), continuîndu-se astfel un tipar concesiv: conector condițional + focalizator (cf. Zafiu, 2014, p. 211).

Conectorul condițional din latină, si (rom. să/se), deși își păstrează chiar în româna actuală ambele valori ( $\boldsymbol{S a ̆ ~ a m ~ b a n i , ~ m i - a s ̧ ~ l u a ~ m a s ̦ i n a ̆ ; ~} \boldsymbol{S} \breve{a}$-mi dai un milion, nu ți-o arăt) n-a reușit, nici în perioada condițională, nici în cea concesivă să dobîndească un sens procedural.

$\mathrm{Cu}$ sens emfatic, se folosea singur în latină: Si bona fortuna veniat, ne intromiseris (TL, p. 41; cf. Slușanschi, 1994, p. 60). Dar fenomenul se întîlnește, cum s-a văzut nu numai în româna actuală, ci și în limba română veche: nu veri scăpa de nevoe, s-ai lăcui în turnul Semireanului, să ai fi îngrădit cu foc (MO, 137 $/ 5-6)$. Un astfel de context probează că conjuncțiile concesive românești nu sînt „toate formate pe terenul limbii române din elemente moștenite din latină” (Frâncu, 2000, p. 209).

Conectorii discontinui se pare că aveau o valoare intensivă mai pronunțată, (intesificatorii aveau un 
comportament deictic), din moment ce, mai ales la tiparul moștenit, structurile sînt frecvente: $s \breve{a} t ̦ i-a r f i$ și tată și mumă macară, feciorii macară să ți-ar fi, deaca se află pizmașii legiei lu Hristosu, să ne potrivimu și noi loru ( $\left.\mathrm{CC}^{2}, 225 / 1-3\right)$; iară să va și grăi aşa de sineși și va mărturisi că are puteare, nicio mărie nu-i iaste $\left(\mathrm{CC}^{2}, 280 / 1-2\right)$.

Discontinuitatea a devenit mult mai frecventă după înlocuirea lui să cu de. Fenomenul s-a produs din cauza coincidenței omonimice $s e(=$ dacă $)$ - se (pronume reflexiv) sau în varianta realizată prin durificare: $s \breve{a}-s \breve{a}$ („,necesitatea de a evita construcția să să va”, Arvinte, 2004, p. LXII). Intrucît dificultatea era generală, aria modificării a fost mai mare, și, cu siguranță, mai veche, culminînd cu textele exemplare: „Cînd au pregătit textul (BB, s.n.) pentru tipar, diortositorii bucureșteni, frații Greceanu l-au „modernizat”, adică l-au adaptat la norma literară sudică, muntenească, înlocuind sistematic, în toate ocurențele, conjuncția să 'dacă', cu conjuncția de” (Arvinte, 2004, p. LXII). Rezultatul: „,conjuncția să 'dacă a dispărut din norma limbii literare moderne pe la şfîrşitul secolului al XVII-lea" (Arvinte, 2004, p. LXII).

Preferința pentru acest conector se poate observa și din frecvența mult mai mare în structura discontinuă de... și: De să ară fiind și nedreptate fiind carea vă e obida aşa rea (СВ-CP, 195, 3-4); de te și grijești, ome, și să și socotești, nemică nu veri face, deaca nu va vrea Dumnezeu ( $\left.\mathrm{CC}^{2}, 242 / 18-19\right)$; Că de au și fost răstignit den slăbiciune, încă viiază den putearea lui Dumnezău (Nтв, Cor, 13, 4); Că de v-am și întristat pre voi cu cartea mea, nu mă căiesc, să m-am și căit (...) v-au întristat pre voi (NTB, Cor, 7, 8); iară de or și präda-o, nemic n-a bi decît să le ie ienicerii muierile (IN, 288, 2/13-14); carele lucru d-ar fi și fost (...) nici o laudă, nici o cinste n-ar fi fost ( $\left.\mathrm{AB}, 118^{\mathrm{v}} / 3-4\right)$; Și de sînt și rob, astăzi am căzut în robie, iară tu ești rob de cînd te-au făcut tată-tău (AB, 121 v/41-42); De au și fost vreo jiganie rea, dulăul au gonit-o (CI, 89/5-6).

Cum s-a arătat, există un număr mare de alofunctive ale conectorului concesiv, în exprimarea diferitelor valori, determinate de modalitățile impuse de predicat și de diversitatea contextelor, între real, potențial (condițional) și ireal. Pe lîngă cele exemplificate anterior există mult mai multe, cu multe variante fiecare, traversînd, cum se poate vedea din exemplificări, primele trei secole de cultură scrisă românească.

Chiar dacă nu este foarte frecvent, deși apare încă de la început, cînd se desfășurau experimente formale cu ceilalți conectori: fu de la domnul propovedire, spăsenie și înviere, deși ainte a morților înviere (СВ-CР, 297/3-4); Iară, deși ai tu, nu te lăuda, că de la Dumnezeu le-ai luat (INB, I, 8/32, 9/1); că deși era răpit la vremea sa, iară nu îndelungu (MC, 169, 1/20-21); Ce de și oblicie Antonie-vodă încă nu le dzice nemic (IN, 299, 1/3-4); Deși vedzi cîndva sămn groaznic să nu te miri (VO, 1 /1-2), Deși înaintea oamenilor cazne au pățit, nedejdea lor de nemoarte plină iaste (CD, 73 /15-16); căa deși peste tot și tuturor glasul Corbului iaste neplăcut, avem între noi Coțfana (CI, 55/11-12); că, deși tăcerea, între noi iubitorii înțelepciunii lăudată iaste, însă la vreme de treabă icoana neștiinții arată (CI, 104/4-5).

Considerat „cel mai vechi și mai stabil conector concesiv (sau component al unor conectori concesivi) din limba română” (Zafiu, 2015, p. 678), jonctivul cu baza măcar are cea mai interesantă evoluție, începînd cu latina populară, care l-a preluat din greacă ( $\mu \alpha x \alpha ́ \rho \iota)$, continuînd cu limbile balcanice și romanice. La nivelul configurației formale, cunoaște o mare disponibilitate, de la adverbul simplu, pînă la hiperfunctiv. Dar aceasta nu l-a salvat de la regresie, deoarece „Din a doua jumătate a secolului al XIX-lea, conectorii concesivi care îl conțin sînt înlocuiți în limba standard de alți conectori total sau parțial gramaticalizați” (Zafiu, 2015, p. 678).

Cînd apare singur, valoarea adverbială, opusă lui altminteri este mai pronunțată: Măcar sărac, măcar mişel, cu multă multă mulțumire să laude pre Dumnezeu (INB, I, 30/22-23); împăratul, cît de mult setos find, măcară mulțime de izvoară avea (Bв, Iosip, 3/22-24); partea trupului cea roditoare, carea în cevași macară betejindu-se, de grabnică moarte aducătoare iaste (CI, 23/10-13); Ce măcară noi, sau ingerul din ceriu va propovădui voao altă (...), anatema să fie (NTB, Gal, 1, 8); nimic alt n-au mai căutat, măcar un salam malichim de la musaip să auză ( $\left.\mathrm{AB}, 130^{\mathrm{V}} / 44-45\right)$; pe legheoanele romane, carii de curînd era adaose acolo, nu le-am putut piiarde, măcară între varvari cufundați era (ITR, 72\% /12-13).

Acest semiadverb intensiv a funcționat ca intensificator pe lîngă foarte multe conjuncții: Să pue domn strein, măcar și din feciorii de domn ce era la Țarigrad (AB, 114²/48-49); Măcar și de șapte ori de va greși fratele tău (...) iartă-i lui (N TB, 93 
cei mai mulți (вв, 2Mac, 736, b, 47-48); lucrul său îl știia purta, macară că era tînăr de zile (GU, 73, a, 23-24); s-au aședzat la domnie măcară că era de mare credință la impărățiie (MC, 153, a, 11-12); pasire iaste, măcară că carnea la gust îi iaste ca a delfinului și măcară că precum prin aer cu slobozie poate umbla (CI, 26/8-10); Măcar să acei boieri era greci, dar să pune tare pentru țară (IN, 278, a, 2-3); nimeni să nu să amăgească și să să ție mare, măcar să fie împărat, măcar domnu, măcar boiariu, măcar fiește ce va fi (INB, I, 43/8-10); Măcar de s-ar și pleca noao, de ce treabă ne-ar fi noao sau pardosu măcar de ar fiși blindu (INB, I, 12/18-19); Măcar de vei birui, măcar de te vor birui, aceia tot să fie lîngă tine (INB, VIII, 217/19-20); Și măcară casă de să va împărți pre sine, nu poate sta casa aceaea (Bв, Mc, III, 25); Măcar de v-aru și poronci domnul, atunce... (IN, 299, b, 1-2).

Există însă şi alte asocieri care nu s-au impus ulterior în limbă. Una dintre acestea este asocierea redundantă: Iată, măcar deși grăiaște de făpturi, iară de ingeri nu pomeneaște (INB, I, 23-24); nici să se obrăznicească în biruințele lor a-i lăsa, ci, măcar deși lega cîteodată cu ei pace... (ITR, 11 1/10-11); Măcar deși ceva bun cu darul lui Dumnedzău de la tine au ieșit, nu te, pentru aceasta cu sufletul inălța, nici te cu firea îmfla $\left(\mathrm{CD}, 132^{\mathrm{v}} / 19-21\right)$; că măcar săvai că iaste și tras în nevodul sventei evanghelii, săvai că iaste și în beserecă cu credincioșii $\left(\mathrm{VO}, 158,223^{\mathrm{r}} / 14-15\right)$.

Șansa de a se impune n-au avut-o nici construcțiile cu relatori: măcară cît am ostenit, cît am cercat, cît am întrebat... (ITR, 2v/6-7); măcar cum mai mult dobitoacelor în patru picioare asemănîndu-te... (CI, 21/11-12); macarcare, macarcine, macarîncotro, macarunde (DVL, p. 201-202).

Unii conectori nu au rezistat în limbă, deși într-o anume perioadă au fost frecvenți. Astfel construcția pe teren românesc săvai (să-vrea, să-vreai - săva, săvai). Despre ea s-a afirmat că a apărut în secolul al XVII-lea (Stan, 2013, p. 256), dar, așa cum arată exemplele, adverbul săva, pe lîngă alte valori, impune și un sens concesiv, încă din secolul anterior: săva fie nămearnic de laturi, săva lăcuitoriu de aicea sufletul aceluia va pieri (PO, 12, 19); săva bou fie, săva asin, săva oaie de doao orisă dea atîta (PO, 22, 4); săva bou fie, săva asin, săva oaie săva veșmînt, săva aceacea ce-ai pierit ( $\mathrm{PO}, 22,9)$.

Ulterior, adverbul concesiv, chiar cel apropiat de forma etimologică, s-a asociat cu alți conectori, asumîndu-și pe deplin concesivitatea: am putut și greși, săva că am silit de cît am putut să nu greșim (NT B, Pred., 116); scrisără și ei evanghelii, săva că au fost și alții mulți care eu scris evanghelii (NTB, Pred., 118); nu fuiu mai mic decît apostolii cei mari, săva că nemică sînt (NT B, Cor, 12, 11).

Cealaltă variantă apropiată de structura etimologică se întîlnește rar, evoluînd la săvai, asociindu-se frecvent cu diverși conectori: săveri că-mi era mie poarta deșchisă pren Domnul, nu avuiu răpaos sufletului mieu (NTB, FA, 2, 12); săvai că foarte cu durere dă inemă și întristăciune la toți (...) atît carele cît și oamenii, in fermanu poruncea (RG, 256/3-4); au purces arătînd grabnică gătire (...) săvai că pornirea le-a fost numai mănioasă și groaznică (RG, 326 $\left.{ }^{\mathrm{V}} / 3-4\right)$ ); au fost de fel dacu, săvai că forte puțini rămăsease (ITR, 21 ${ }^{\mathrm{r}}$ ); săvai vii, săvai deaca murim, a lui Dumnedzeu sintem (Vo, 31v, 13-14); Săvai de ți s-ar ruga vrăjmaşul cu glas mare, să nu-l asculți (вВ, Sol, XXVI, 25); Și săvai de cătră împuținarea vîrtutei să va opri a păcătuit, de va afla vreame a face rău (BB, Inț, XIX, 24); Că săvai și mai multu de mă voiu lăuda pentru putearea noastră (...) nu mă voiu ruşina (в в, Cor, X, 8).

Matricea semantică a perioadei concesive (chiar dacă... totuşi) s-a realizat încă de la început integral: Căci care viețuiescu întru bunătăți oare să voru avea bogăție, oare meserătate, totuși e lucru bunu și cu spăseniia și bine ( $\left.\mathrm{CC}^{2}, 27-29\right)$; să ş-ai arunca această în trei părți, de chinu născătoare, totu impotrivă aflăse săgetarea ei ( $\left.\mathrm{CC}^{2}, 11-13\right)$; să și scapă aceia înşişi de aceaia, iară ai loru moșteani totuşu au cu aceaia a se chinui și a se osindi ( $\left.\mathrm{Cc}^{2}, 500 / 21-23\right)$.

Relația dintre circumstanțial și propoziția corespunzătoare este asigurată de configurația subordonatei relative, întrucît conectorii relativi îndeplinesc și funcție sintactică.

Dar circumstanțialul concesiv este mai bine reprezentat decît cel condițional. Uneori este prezent și corelativul: Cîte răutăți facem, iar Dumnezeu tot ne învrednicește cu cinste (INB, I, 11/10-11); Și orîncătro și spre ce vrăjmaşi de ai tăi vei merge, tot îi vei birui și-i vei pune suptu picioarele tale (INB, I, 19/10-11).

Tiparul grupului prepozițional (în ciuda, în pofida, in pizma, impotriva) nu se gramaticalizase încă (cf. Frâncu, 1977, p. 15-26): să nu gîndiți că doară pre voia cuiva sau în pizma cuiva (...) s-au scris (IN, 
266, a/16-17); iar amintrile (...) în pizma adevărului socoti (CI, 46/16-18); pre ciuda lumii aceasta din pricinele firești de amănuntul să o ispitim (CI, 117/14-15); Împotriva a toată socoteala driaptă, gîndul și fapta Corbului pre cît mai mult putu a abate sili (CI, 130/4-5).

Destul de frecventă este construcția dominată de adverbe: toate le-au chivernisit săvai cu dăstul pas săracilor (RG, 142 /1); măcară domni, măcară bogați, măcară săraci, tot greșim lui Dumnezeu (INB, I, 5/22-23); măcar numai cu o poruncă a lui Dumnezeu (INB, I, 16/14-15); carea în cevaş măcară betejindu-să de grabnică moarte aducătoare iaste (CI, 23/3-4); lacomul, și sătul flămînd iaste (CI, 39/34). În structuri similare, conjuncția deși (deși sărac...), presupune elipsa copulei, plasînd construcția la nivel frastic.

Conectorii relativi, reprezentaţi de nehotărîtele totalitare (pronume / adjective pronominale și adverbe), introduc frecvent în limba română veche circumstanțiala concesivă: vare ce vrem ceare pre voia lui, asculta-va noi (Св-CP, 370/1-2); Oricîte va greși fieștecarele aproapelui său (...) să-i dai calea lui în capul lui (BB, 3Împ, VIII, 31); I-au poruncit ori cu ce mod va ști, oamenii lui să trimiță să-l prinză (RG, $\left.173^{\mathrm{v}} / 3-4\right)$; oricît va cheltui pentru dînsul, îi va întoarce mai cu asupră cheltuiala (GU, 91, a/1-2); Și ori la cine și ori la ce boieriu mergea cu carte, în picioare sta boieriul pînă să citiia cartea (MC, 169, b/10-12); iară acel omu împărătescu, cine-r hi fostu, au dat samă c-au vădzut (IN, 284, b/16-17); Ori în ce parte vor merge vor prăpădi tot și să vor întoarce (RG, 191 $\mathrm{V} / 12)$; de mi-are face doftoriul să fie bărbatul mieu cu mine, ce mi-are ceare eu t,-oi da (s, 97 $/ 22-24)$.

Dacă la nivel frastic perioada concesivă este, în fapt, expresia unui paradox; la nivel propozițional, corespondentul este un oximoron. Acesta constă în sensul realizat prin neutralizarea unei afirmații printrun antonim: Dulce e somnul robului, săvai puțintel, săvai mult va mînca (BВ, Ecl, V, 11); unde va fi domnul mieu împăratul și săvai la moarte și săvai la viață că acolo va fi robul tău (B , $1 \hat{I} m p, \mathrm{XV}, 22$ ); Și așa turcii, de voie, de nevoie, le-au căutat a sta de război ( $\mathrm{RG}, 123^{\mathrm{v}}$ /12-13); Nu să cade să omori niciunul, ori cu vină, ori färă vină $\left(\mathrm{s}, 86^{\mathrm{r}} / 17-18\right)$; să-l rrădice ori cu voe, ori fără voe, cum vor ști (RG, 329/6-7); ori dă voe să zicem, ori dă nevoie a primi, le-au căutat (RG, 344\% /6-7).

Frecvente sînt cele verbale: ce vrea să-şi astupe ruşinea veri neveri (MC, 170, b/43-44); Si iată că dintradunările voastre vrînd-nevrînd, îm caută a lipsi (CI, 26/3-4); pre carea și vrînd și nevrînd îi va căuta a merge (CI, 124/20-21).

\section{Alte trăsături comune celor două poziţii sintactice}

Pe lîngă aspectele de conținut (legătura dintre condițional și concesiv la nivelul raționamentului ipoteticodeductiv) și cele de formă (obținerea conectorilor concesivi de bază prin focalizarea celor condiționali), există și alte aspecte în zona de interferență a celor două poziții sintactice: tipul de compunere a unor conectori importanți, incidența corelativilor adverbiali și posibilitatea de amplificare a perioadelor la nivelul discursului.

4.1. Ca modalitate de compunere va fi analizată aglutinarea, ce angajează în primul rînd conjuncția de, cu etimologie nesigură. Se dau, de cele mai multe ori, echivalente formale din mediul slav (Ciorănescu, 2001, p. 281).

Caracterul polifuncțional îi conferă o importanță deosebită. La nivelul normei actuale poate regiza 5 raporturi sintactice, chiar dacă acestea au conectori specifici (condițional, cauzal, concesiv, final și consecutiv) (cf. MDA, II, p. 27-28).

Valorile diferite ale acestei conjuncții nu diferă de cele ale compuselor sale, așa cum au fost descrise anterior. Clar condiționale rămîn cele în care predicația se realizează prin timpurile relative ale indicativului și ale condiționalului: Că de ați creade lui Moisi,doară ați creade și Mie (Nтв, In, 5, 46); n-ar hi fostu fără răscoală de nu s-ar fi spăimat Racoți (MC, 188, b/31-32).

Conjuncția de etalează o mare disponibilitate de a realiza compuse prin aglutinare: (deaca, deca, daca) dacă; deşi, deci, decît etc. 
Conectorul tipic condițional dacă s-a obținut din conectorul simplu de și adverbul ca (lat. quam, cf. vsl. jako) în virtutea faptului că în anumite contexte aveau valori similare: de = indată ce, imediat ce, după ce, cînd, cît timp; ca = cînd, îndată ce, după ce (cf. Arvinte, 2004, p. LXI).

Ca și $d e$, functivul $c a$ era polifuncțional, „ceea ce se poate observa și cu ajutorul echivalențelor care se stabilesc între diferitele forme utilizate (atunci cînd acest fapt se întîmplă) în versiunile comparate” (Gafton, 2001, p. 157).

În cele mai multe corelări, echivalența probabilă se face cu deca: iară ca lu îmvise elu din morți nu după aceaia vruindu se întoarce întru putredire (Св, 143/2-3) - E deaca-l invise el den morți, de-aciia acela nu vru a se întoarce în putredire ( $\mathrm{CB}-\mathrm{CP}, 143 / 2-3$ ); Și ca giudecatu fu se nutămu noi întru Italia (CB-CV, 244/6) - Ce ca se judecă fu noao a nota întru Taliia (СВ-СР, 244/5) - Deca judecat fu a nota noao întru Italie (Св, 244/6); Ce ca văzură păgînii spînzurînd șarpele de mîna lui, grăiră unul cătră alaltu (СВ-СР, 257/1-2) - Deci deca vădzură varrvarii spîndzurîndu șarrpele de mînra lui grăiia urul cătră alaltu (CB-CV, $257 / 1-2)$.

Variantele formale ale lui dacă (cf. Gafton, 1999, p. 95-101) au avut o distribuție dialectală relativă. De altfel, în BB, în care zona nordică era reprezentată de Mitrofan, trimisul lui Dosoftei, iar zona sudică de frații Greceanu, se întîlnesc: și deca auzi norodul glasul trîmbițelor au chiuit tot norodul cu chiot mare (B B, Navi, IV, 21-23); Și să făcu deca să suiia zorile și chemă Samuil pre Saul (Bв, 1̂Imp, IX, 27-28); Deaca veți întra în cetate, așa îl veți afla pre el în cetate (BB, 1 Împ. IX, 13-14); Și deaca cu rău veți face rău, și voi și împăratul vostru veț peri (BB, 1Împ, XII, 25-27); Și fu daca săvîrși Solomon zidind Casa Domnului... (вв, 3ÎImp, IX, 1-2); Și fu daca auzi Ierovoam, feciorul lui Navat, și el încă fiind în Eghipet (Bв, 2̂̂Imp, XII, $4-5)$.

În urma acestor tribulații formale, dacă, prin devansarea ca frecvență a celorlalți conectori, reușește să devină un conector tipic condițional, dar nu dobîndește sens procedural, întrucît polivalența din fazele anterioare rămîne activă.

Legea specificității raportului regizat se impune însă, pentru conectorul deci (cf. Gafton, 2011, p. 1521), încadrat mai tîrziu la coordonarea conclusivă. În mod surprinzător, agutinarea cu semiadverbul intensiv și, impune un conector specific, deși. Surprinzător este și faptul că, la condițional, conectorul format prin aglutinare nu s-a impus prin sensul procedural, în timp ce la concesiv, unde sînt mai mult de 5 conectori specifici, s-a impus. $\mathrm{Cu}$ atît mai mult cu cît compunerea prin aglutinare nu s-a mai realizat la raportul concesiv. Sînt consemnate de DVL formațiile nevalidate ulterior de limba literară (macarcare, macarcine, macarunde). S-a arătat, de asemenea, că: „Măcar că este adesea înregistrat în gramaticile de la sfîrșitul secolului al XVIII-lea ca o unitate sudată" (Zafiu, 2015, p. 681): macarché, macarque, mecarquo...

4.2. Așa cum s-a arătat, un raport circumstanțial este caracterizat, la nivel frastic, de o structură corelativă, reluarea făcîndu-se, de regulă, printr-un adverb semantic plin, ce domină clasa de substituţie a circumstanțialului respectiv la nivel propozițional. Corelarea dintre protasă și apodoză se face, în cazul celor două raporturi sintactice prin mai multe adverbe (cf. Avram, 1960, p. 153-201). Dar, în mod surprinzător, printre adverbele corelative, foarte frecvente sînt conjuncțiile adversative. Referitor la concesiv s-a arătat: „Un raport de același fel poate fi exprimat și printr-o structură bipropozițională cu termeni de același rang coordonaţi prin dar sau însă (...) Deși nu este cuminte, îl iubește toată lumea - Nu este cuminte, dar/însă îl iubește toată lumea" (GALR II, p. 592). Corelativele adversative, în limba română veche, dar și în limba populară actuală (cf. exemplul citat frecvent: Deși ești diavol, dar ți-e mintea goală), se întîlnesc și după protaza condițională.

Exemple se pot da multe: De vor fi păcatele voastre întunecate sau de vor ficrunte ca sîngele, iar eu le voi face ca lîna cea albă (INB, I, 51/2-3); De nu ne veți da, iar noi vom lua și făr'de voia voastră (INB, I, 22/1314); deaca muri unul pentru toți, iară toți am fost morți (N T B, 1Cor, 5, 15); Că de ar fi fost jidoveaște scrisă, dară cine o ară fi intors greceaște, cu adevărat nime nu ști (NTB, Mt, Pred., 119); De voi intrista eu pre voi, dară cine iaste să mă veselească (N $\mathrm{NB}, C$ or $, 2,2)$; de-l vor vedea că ieste pre moarte, iară ei să-l călugărească (GU, 100, b/31-32); De ai uitat tu, dar eu n-am uitat (IN, 277, b/9-10). 
La fel de multe se pot da și pentru concesivă, cu cele mai multe tipuri de conectori: să și n-avămu a trupului boală, iară inima noastră de pururea e păzită (CC $\left.{ }^{2}, 433 / 17-18\right)$; Măcar de-și învăța și-i certa, iar cu toiagul nu vrea să-i bată (INB, I, 24/20-21); Că omul, deși cunoscu el însuşi păcatul și vina sa, iar Dumnezeu tot îl lăsă să fie încorunat (INB, I, 12/4-5); de am și cunoscut trupește pre Hristos, iară acum nuI mai cunoaștem (в В, 2Cor, 5, 16); săva că mulți cărtulari țin așea, că-i scrisă jidoveaște, iară mai mulți să indoiesc (NT B, Pred., 119); Săvai că înșiş de sine și nu știu svinții de noiși de rugămintea noastrăa, iară după darul lui Dumnezeu (...) toate le știu (Vo, 28 r, 3-5); Săvai că poate zice neștine că să află și aici letopisețe, ci răspunsul îi iaste gata (ITR, $3^{\mathrm{r}}$ /10-11); Ci măcar că deodată au alinat lucrul, iară mai apoi Dispot de isnoavă mai bine s-au gătit (GU, 88, a/21-22); că măcar că lovisă și pe Cantemir pașea, iară leșii (...) răsipă acestor orde a face n-au putut (MC, 171, b/22-23); macar că cu chinuri și dureri, însă suffere și priimește (CI, 50/1-2); macar că viderea ochilor mai ascuțită s-au păzit, însă neștiințta în întunerecul și în tartarul necunoștinții i-au vîrît (CI, 63/22-23); măcar că din fire orb și slut era, însă fietecarile (...) îl îndemna (CI, 144/7-8); măcară că la mai multe n-au nemerit, de a grăi de firile lor adevărul, iară încăș destul că tot am pomenit (ITR, $\left.1^{\mathrm{v}} / 12-13\right) \ldots$

Faptul că fenomenul este atît de extins, întîlnindu-se chiar în textele „oficializate” (NTB, BB), arată că a fost în norma epocii o perioadă îndelungată de timp.

Este posibil ca din textele de cult să fi trecut, în timp, în limba populară: Deși ești diavol, dar ți-e tigva goală (apud Graur, 1956, p. 130); Căruța lui, deși era ferecată cu teie, cu curmeie, însă era o căruță bună (apud Graur, 1956, p. 130); Chiar dacă-i ea mai urîtă, da vorba aia, am pămînt, am ce munci (apud Teiuș, 1980, p. 125).

Căutînd să explice raportul de implicație semantică, gramaticienii n-au putut trece de formalismele tradiționale, constatînd, numai pentru concesivă, existența coordonării între principală și subordonată (Graur, 1956, p. 130; Avram, 1960, p. 212).

Pentru găsirea unei înțelegeri, s-au invocat mai multe argumente: comparația cu structura corelativă tipic circumstanțială de tipul acolo..., unde; sinonimia dintre relația concesivă și coordonarea adversativă, justificîndu-se interferența printr-o presupusă relație de interdependență: subiect psihologic (concesiva) predicat psihologic (principala) (Dragomirescu, 1984, p. 527). S-a arătat chiar că, exprimînd conținuturi contrastante, sensul procedural al conectorilor adversativi coincide cu cel al conectorilor concesivi, progresînd de la contrastul semantic, pînă la contrazicerea așteptărilor (Zafiu, 2005, p. 247). Acest din urmă argument nu vizează utilizarea simultană a conectorilor concesiv și adversativ, dar evidențiază specificul semantic.

Corelația circumstanțială impune ca adverbul să aibă funcție sintactică, ceea ce se întîmplă în corelația concesivă (chiar dacă..., totuşi), dar nu se întîmplă în cazul conjuncțiilor adversative.

Sinonimia concesiv-adversativ, așa cum au demonstrat studiile de pragmatică actuală, este reală, dar corelativele adversative se găsesc și în perioada condițională, de care gramaticienii, de regulă, nu vorbesc.

Pentru concesivă, surpriza a venit din reperarea unor enunțuri în limba actuală (alta decît cea populară), în limbajul presei (Eu, deși mă bucuram cînd izbuteam ceva, dar în conștiința mea socoteam...) sau din traduceri (Deși au făcut același lucru, însă erau conduși de alte scopuri) (cf. Zafiu, 2005, p. 247).

În secolul al XIX-lea corelarea adversativă a concesivelor și condiționalelor întră în regresie (cf. Merlan, 2001, p. 183).

Fenomenul a fost descris cu alte „argumente”: „o anomalie în sintaxa limbii române actuale (...), contestabilă din punctul de vedere al cultivării limbii (...) nu poate fi tolerată”; „o suplimentare aberantă a conjuncțiilor coordonatoare (...) creînd un anacolut cu totul neplăcut”" (Dragomirescu, 1984, p. 526) etc.

În latina veche și în cea populară cele două tipuri de implicaţie dinspre subordonată spre regentă (condiționala și concesiva), erau considerate și construite ca principale, „constituind, probabil, o moștenire indo-europeană” (Iordache, 2002, p. 44). Într-o altă fază de evoluție, latina clasică a recurs pentru protază (falsă principală) la conjuncții subordonatoare (p. 66). Condiționala a trecut prin aceleași faze, de la falsa principală, la o relație hipotactică, comportamentul similar fiind justificat de „relațiile logice și gramaticale între propozițiile condiționale și cele concesive” (p. 116). Așadar au început să coexiste (falsele) principale 
condiționale și concesive, cu subordonatele respective, nu numai în limba română, ci și în celelalte limbi romanice (p. 98).

Întrucît faptele de latină populară sînt mai greu reperabile, fenomenul poate fi „modelat” pentru raportul concesiv, și prin latina clasică, în care cele două procedee, așa cum s-a arătat, coexistau.

Astfel, în mod frecvent, adverbul corelativ care marca opoziția („contrazicerea aşteptărilor”), tamen (cf. rom. totuşi), din perioada „coordonării” era precedat frecvent de conjuncții coordonatoare: et/at, sed, verum (et tamen = și totuşi; sed/verum tamen = dar totuşi) (Iordache, 2002, p. 46; cf. și Guţu, 2003, p. 1312; cf. și Ernout \& Meillet, 1994, p. 674).

Dintre acești conectori coordonatori, et nu era adversativ, aşa că rareori putea regiza perioada concesivă (cf. rom. Să-mi dai un milion și nu te las): deci, se aplică și de această dată legea conservării excepțiilor. În rest, s-a asociat cu semiadverbul cu sens totalitar tot (și tot, totuşi), impunîndu-se în norma literară, cu sens procedural concesiv (cf. Ragea, 2010, p. 279).

Sed și verum, conjuncții coordonatoare adversative, datorită sensului lor opozițional (cf. și Niculescu, 1965, p. 102: „conjuncțiile concesive (...) multe manuale de gramatică le trec în rîndul adversativelor”), puteau exprima și singure implicația condițională și concesivă, ceea ce, cum s-a văzut din exemple, s-a întîmplat în limba română o lungă perioadă de timp, spre nedumerirea unor gramaticieni. Numai că, în mod cu totul special, raportul concesiv și-a construit, încă din limba română veche, un număr mare de conectori specifici (cu sens procedural), încît s-a putut dispensa de aportul adversativelor, cu un sens atenuat faţă de forța focalizatorilor.

4.3. O altă asemănare între raportul condițional și concesiv este acela al organizării lor sub forma unor perioade gramaticale, ca expresie a unui raționament ce presupune exersarea capacităţii analitice a gîndirii. Perioada condițională și, în mai mare măsură cea concesivă, nu se derulează prin automatismele care asigură fluența limbajului, ci sînt enunțuri pentru care este convocată gîndirea. Protaza anunță un sens pe care apodoza îl întoarce (concesiva) sau îl confirmă (condiționala). Completîndu-se una pe alta, au un conținut semantic finit, închis, de aici senzația de circularitate, de unde le vine și numele (gr. periodos $=$ drum ocolit).

Pe măsură ce capacitatea analitică a vorbitorilor s-a exersat la nivelul limbajului natural, de la perioadele sintactice, s-a trecut la perioadele oratorice, prin utilizarea unor procedee mai rafinate: paralelismul, amplificarea, repetiția, circularitatea... (cf. Munteanu, 1998, p. 77-78).

În limba română veche, cel mai des acest lucru s-a făcut prin exercițiul traducerii, incidența trăsăturilor periodice fiind destul de mică: Es-ară neştine zice că iubeaște Dumnezeu, e fratele său nu iubeaşte, minciună iaste și, amu, să nu iubire fratele său ce-l veade e Dumnezeu ce nu-l veade cum să-l poată iubi? (Св-СР, 365/3-5); Că de nu ne vămu pocăi și de nu ne vămu delunga de hitleniile noastre și de nedereptăți și bunătățile nu ne vămu nevoi să le facemu, avămu a peri dreptului judecătoriu și mîniei lu Dumnezeu (cC ${ }^{2}$, 234/8-11).

Perioadele concesive sînt mai rare și mai ample, fiind mai greu de închis: Es-amu fiși goniţi de nescare oameni necredincioși, săne-arășispînzura și să ne-ară și sparge cu moarte grozavă, s-amu fiși ucișuși să ne-ară munci în toate chinurele cealea realele, pentru dumnezeiasca credință, iară noi de acealea să nu ne întristămu, ce mai vîrtosu să ne bucurămu (cc², 128/19-24).

Amplificarea la Cantemir, semnalată grafic prin paranteze, devine un procedeu caricatural, autorul fiind preocupat nu de închiderea sensului, ci de disiparea lui: Măcară cum mai mult dobitoacelor cu patru picioare asemănîndu-te (precum singură tu cu al tău cuvînt ți-ai legat) (căci la cel cunoscătoriu mai tare să ține și iaste legătura hireșului cuvînt decît frenghiia întreită de la altul înfăşurată), mai mult în cumpăna dobitoacelor greuimea dreptății să pleci și după fățărnicia priinții, iară nu după pohta dreptățiii, giudecata să abați (CI, 21/11-17).

Antim Ivireanul însă, la concurență cu Hrisant Notaras de la curtea lui Brîncoveanu, stăpînea adevărata artă a oratoriei, exercitînd diverse strategii argumentative și persuasive (cf. Guia, 2014, p. 235; cf. şi Guia, 2002-2004, p. 340): și măcar că eu am fost mai mic și mai netrebnic decît toț... dară Dumnezeu n-au 
căutat la micşorarea și netrebniciia mea, nu s-au uitat la sărăciia mea și streinătatea mea, $n$-au socotit prostiia și neștiințta mea, ci au căutat la noianul bunătății sale și au acoperit de cătră oameni toate spurcăciunile și fârdelegile mele, care sînt mai multe decît perii capului mieu și decît năsipul mării și m-au înălțat, nevrednic fiind, la această stepenă și mare vrednicie a arbieriei (AI, 5\%/25-34).

Perioadele sintactice (condițională și concesivă) au contribuit la exersarea capacității analitice a gîndirii. Pe măsura trecerii acestora în automatismele vorbirii prin asumarea sensurilor procedurale ale conectorilor, au făcut posibilă implicarea componentelor afective ca vector de persuasiune în perioadele retorice.

\section{Concluzii}

Abordarea celor două modalități de manifestare a raționamentului ipotetico-deductiv sau condițional prin intermediul perioadelor condiționale și concesive s-a axat pe conectorii de bază ai celor două poziții sintactice de la nivel frastic, evidențiind felul în care limba română și-a perfecționat în timp instrumentarul sintactic pentru exprimarea celor trei dimensiuni (real, ipotetic și ireal) ale unui mesaj complex.

Valorile condiționale, întrucît corespundeau raționamentului direct, deși au cunoscut un număr mare de încercări / variante, n-au reușit să ajungă la sensul procedural decît printr-un singur conector (în caz $c \breve{a})$, celelalte rămînînd în sfera conectorilor polifuncționali.

$\mathrm{Nu}$ acelaşi lucru s-a întîmplat cu conectorii concesivi. Dificultatea paradoxului semantic a determinat vorbitorii la mai multe încercări, la elaborarea unui sistem focal, din semiadverbe intensive, pentru a fixa într-un mod cît mai clar nucleul semantic al concesivității. Rezultatul a fost dobîndirea sensului procedural pentru un număr mult mai mare de conectori: cel mai mare număr de conectori specializați pentru o poziție sintactică. Acest lucru a fost posibil prin activarea, la nivelul normelor, a raportului dintre continuitate și creativitate.

\section{Bibliografie}

\section{A. Studii}

Arvinte, V. (2004). Normele limbii literare în Biblia de la București (1688), Editura Universității „Alexandru Ioan Cuza”, Iași. Avădanei, Șt.., Călinescu, Al., Ciopraga, M. \& Panaitescu, V. (1994). Terminologie poetică și retorică, Editura Universității „Alexandru Ioan Cuza”, Iași.

Avram, M. (1960). Evoluția subordonării circumstanțiale cu elemente conjuncționale în limba română, Editura Academiei, București.

Barbu, N.I. (1943). Sintaxa limbii române după metoda istorico-stilistică, Editura Gina, București.

Bujor, I. \& Chiriac, Fr. (1971). Gramatica limbii latine, Editura Științifică, București.

Căpățînă, C. (2007). Sintaxa limbii române, Editura Universitaria, Craiova.

Ciorănescu, Al. (2001). Dicționarul etimologic al limbii române, Editura Saeculum, București.

DELLR = Dictionnaire des emprunts latins dans les langues romanes, Editura Academiei, București, 2004.

Densusianu, Ov. (1961). Istoria limbii române, II, Editura Științifică, București.

DLRLC = Dicționarul limbii române literare, contemporane, I, Editura Academiei, București, 1955.

Dominte, C. (2003). Negația in limba română, Editura FRM, București.

Drăganu, N. (1945). Elemente de sintaxă a limbii române, Institutul de Lingvistică Română, București.

Dragomirescu, Gh.N. (1975). Mică enciclopedie a figurilor de stil, Editura Științifică și Enciclopedică, București.

Dragomirescu, Gh.N. (1984). „Coordonarea adversativă" a concesivei cu regenta ei, în LR, XXXIII, p. 526-530.

Ernout, A. \& Meillet, A. (1964). Syntaxe latine, Klincksieck, Paris.

Ernout, A. \& Meillet, A. (1994). Dictionnaire étymologique de la langue latine. Histoire des mots, Klincksieck, Paris.

Frâncu, C. (1977). Formarea și evoluția complementului concesiv in limba română, în SCL, XXVIII, nr. 1, p. 15-26.

Frâncu, C. (2000). Conjunctivul românesc și raporturile lui cu alte moduri, Casa Editorială Demiurg, Iași.

Frâncu, C. (2009). Gramatica limbii române vechi (1521-1780), Casa Editorială Demiurg, Iași.

Gafton, Al. (1999). Su alcuni valori della congiunzione deca in alcune versioni dell' Apostol del secolo XVI, în AUI, II, p. 95-102.

Gafton, Al. (2001). Evoluția limbii române prin traduceri biblice din secolul al XVI-lea. Studiu lingvistic asupra Codicelui Bratul, in comparație cu Codicele Voronețean, Praxiul Coresian și Apostolul Iorga, Editura Universității „Alexandru Ioan Cuza”, Iași.

Gafton, Al. (2011). Donc, în „Langue et litterature. Repères identitaires en contexte européen”, nr. 8, p. 15-21.

GALR II = Guțu Romalo, V. (coord.) (2008). Gramatica limbii române, II. Enunțul, Editura Academiei Române, București.

Graur, Al. (1956). Pentru o sintaxă a propozițiilor principale, în vol. Studii de gramatică, I, Editura Academiei, București. 
Guia, S. (2002-2004). Strategii argumentative în Didabiile lui Antim Ivireanul, în „Analele științifice ale Universității Alexandru Ioan Cuza”, secțiunea Literatură, tomul XLVIII-L, p. 136-150.

Guia, S. (2014). Discursul religios. Structuri și tipuri, Editura Universității „Alexandru Ioan Cuza”, Iași.

Guțu, Gh. (2003). Dicționar latin-român, Editura Humanitas, București.

ILRA = Sala, M. \& Ionescu-Ruxăndoiu, L. (coord.) (2018). Istoria limbii române, I, Editura Univers Enciclopedic Gold, București.

ILRL = Gheție, I. (1997). Istoria limbii române literare. Epoca veche (1532-1780), Editura Academiei, București.

Iordache, R. (2002). Exprimarea ideii de concesie în limba latină, Editura Paideia, București.

Iordan, I. (1954). Limba română contemporană, Editura Universității, București.

Iordan, I. \& Robu, Vl. (1978). Limba română contemporană, Editura Didactică și Pedagogică, București.

Irimia, D. (2008). Gramatica limbii române, Editura Polirom, Iaşi.

Ivănescu, Gh. (2004). Curs de sintaxa limbii române moderne, Junimea, Iași.

MDA = Micul dicționar academic, II, D-H, Editura Univers Enciclopedic, București, 2002.

Merlan, A. (2001). Sintaxa limbii române. Relații sintactice și conectori, Editura Universității „Alexandru Ioan Cuza”, Iași.

Munteanu, Șt. (1998). Studii de lingvistică și de stilistică, Editura Pygmalion, Pitești.

Niculescu, Al. (1965). Individualitatea limbii române între limbile romanice. Contribuții gramaticale, Editura Științifică, București.

Ragea, O.A. (2010). Sensul procedural al conectorilor concesivi deși și totuşi, în Limba română: controverse, delimitări, noi ipoteze. Actele celui de-al 9-lea Colocviu al Catedrei de Limba Română, II. Secțiunea Pragmatică și stilistică, Editura Universității din București, București.

Riemann, O. (1932). Syntaxe latine d'apres les principes de la grammaire historique, Librairie Klincksieck, Paris.

SLR = Avram, M. (coord.) (2007). Sintaxa limbii române în secolele al XVI-lea-al XVIII-lea, Editura Academiei Române, București.

Slușanschi, D. (1994). Sintaxa limbii latine, II. Sintaxa frazei, Editura Universității din București, București.

Stan, C. (2013). O sintaxă diacronică a limbii române vechi, Editura Universității din București, București.

Teius,, S. (1980). Coordonarea în vorbirea populară românească, Editura Științifică și Enciclopedică, București.

Tiktin, H. (1945). Gramatica română. Etimologia și sintaxa, Editura Tempo, București.

Trandafir, Gh.D. (1996). Alte probleme controversate de gramatică a limbii române actuale și de lingvistică generală, Editura Universității din Craiova, Craiova.

Wagner, R.L. (1966). Grammaire du français classique et moderne, Hachette, Paris.

Zafiu, R. (2005). Conjuncțiile adversative în limba română. Tipologie și niveluri de incidență, în Pană Dindelegan, G. (coord.), Limba română, Structură și funcționare, Editura Universității din București, București.

Zafiu, R. (2014). Stadii în gramaticalizarea conectorilor concesivi: tiparul conector condițional + focalizator în româna din secolele al XVI-lea - al XVII-lea, în Limba română: diacronie și sincronie în studiul limbii române, I. Gramatică. Fonetică șifonologie. Istoria limbii. Filologie, Editura Universității din București, București, p. 211-226.

Zafiu, R. (2015). Marcatorul concesiv măcar în diacronie (secolele al XVI-lea-al XVIII-lea), în vol. Inspreși dinspre Cluj, Contribuții lingvistice: omagoi profesorului G. G. Neamțu la 70 de ani, Editura Scriptor și Editura Argonaut, Cluj-Napoca, p. 678687.

\section{B. Surse}

A = Alexandria, Studiu introductiv, ediție și glosar de Florentina Zgraon, Fundația Națională pentru Știință și Artă, București, 2006.

AB = Istoria Țării Românești (Anonimul Brîncovenesc), Ediție întocmită de Constantin Grecescu, Editura Științifică, București, 1959.

AI = Antim Ivireanu, Opere, Ediție critică și studiu introductiv de Gabriel Ștrempel, Editura Minerva, București, 1972.

вв = Biblia adică Dumnezeiasca Scriptură a Vechiului şi Noului Testament, Editura Institutului Biblic și de Misiune a Bisericii Ortodoxe Române, București, 1988.

$\mathrm{CB}=$ Codicele Bratul, Ediție de text de Alexandru Gafton, Editura Universității “Alexandru Ioan Cuza”, Iași, 2003.

$\mathrm{CC}^{2}=$ Carte cu învățătură (1581), publicată de Sextil Pușcariu și Alexie Procopovici, Atelierele Grafice Socec \& Co., București, 1914.

CD = Dimitrie Cantemir, Opere (Divanul), Ediție Stela Toma, Virgil Cîndea, Nicolae Stoicescu, Editura Academiei Române, Univers Enciclopedic, 2003.

CI = Dimitrie Cantemir, Opere (Istoria ieroglifică), Ediție Stela Toma, Virgil Cîndea, Nicolae Stoicescu, Editura Academiei Române, Univers Enciclopedic, 2003.

Cs = Codex sturzanus, Studiu filologic, studiu lingvistic, ediție de text și indice de cuvinte de Gheorghe Chivu, Editura Academiei Române, București, 1993.

CT = Tetraevanghelul lui Coresi, Ediție de Florica Dimitresccu, București, 1961.

$\mathrm{CV}=$ Codicele voronețean, Ediție critică, studiu filologic și studiu lingvistic de Mariana Costinescu, Editura Minerva, București, 1981. 
$\mathrm{DVL}=$ Dictionarium Valachico-Latinum. Primul dicționar al limbii române, Ediție de Gh. Chivu, Editura Academiei, București, 2008.

F = Fiziologul. Archirie și Anadan, Ediție de V. Guruianu, Magdalena Georgescu, Editura Minerva, București, 1997.

FD = Floarea darurilor, în vol. Floarea darurilor. Sindipa, Ediție de Alexandra Moraru, Magdalena Georgescu, Editura Minerva, București, 1996.

GU = Grigore Ureche, Letopisețul Țării Moldovei, Ediție de Tatiana Celac, Editura Hyperion, Chișinău, 1990.

IN = Ion Neculce, Letopisețul Țării Moldovei, Ediție de Tatiana Celac, Editura Hyperion, Chișinău, 1990.

INB = Învățăturile Sfintului Voievod Neagoe Basarab către fiul său Theodosie, Ediție Dan Zamfirescu, Editura Roza Vînturilor,

București, 2010.

ITR = Istoriia Țărîi Rumînești, atribuită Stolnicului Constantin Cantacuzino, Ediție critică, studiu filologic, studiu lingvistic, glosar și indice de nume proprii de Otilia Dragomir, Editura Academiei Române, 2006.

MC = Miron Costin, Letopisețul Țării Moldovei, Ediție de Tatiana Celac, Editura Hyperion, Chișinău, 1990.

MO = Mihail Moxa, Cronica universală, Ediție critică, însoțită de izvoare, studiu introductiv, note și indici de Gheorghe Mihăilă,

Editura Minerva, 1989.

NTB = Noul Testament (1648), Editura Episcopiei Ortodoxe Române, Alba Iulia, 1988.

PH = Psaltirea Hurmuzaki, Studiu filologic, studiu lingvistic și ediție de Ion Gheție și Mirela Teodorescu, Editura Academiei

Române, 2005.

Po = Palia de la Orăştie (1682), Text stabilit și îngrijire editorială de Vasile Arvinte, Ioan Caproșu și Alexandru Gafton, Editura Universităţii „Alexandru Ioan Cuza”, Iași, 2005.

Prav.1581 = Pravila ritorului Lucaci, Ediție Ion Rizeacu, Editura Academiei Române, București, 1971.

RG = Radu logofătul Greceanu, Istoria domniei lui Constantin Basarab Brîncoveanu voievod (1688-1714), Studiu introductiv şi ediție critică întocmite de Aurora Ilieș, Editura Academiei Române, 1970.

S = Sindipa , în vol. Floarea darurilor. Sindipa, Ediție de Alexandra Moraru, Magdalena Georgescu, Editura Minerva, București, 1996.

SOR = Pană Dindelegan, G. (coord.) (2016). The Syntax of Old Romanian, Oxford University Press, Oxford.

$\mathrm{TE}=$ Coresi, Tîlcul evangheliilor și Molitevnic rumînesc, Ediție critică de Vladimir Drimba, cu un studiu introductiv de Ion Gheție, Editura Academiei Române, București, 1998.

$\mathrm{TL}=$ Théatre latin, Plaute, Térence, publiés par Georges Ramain, Librairie Hachette, Paris, 1897.

Vo = Varlaam, Opere, Răspunsul împotriva Catihismului Calvinesc, Ediție critică, studiu filologic și studiu lingvistic de Mirela Teodorescu, Editura Minerva, București, 1984.

VO = Varlaam, Opere, Carte românească de învățătură, Răspunsul împotriva Catibismului Calvinesc..., Alcătuire, transcriere a textelor, note și comentarii, glosar și bibliografie de Manole Neagu, Editura Hyperion, Chișinău, 1991. 